\title{
Accountability And Transparency Of Sharia Micro Financial Institutions On Customer Trust With Financial Performance As An Intervening Variable
}

\author{
Dewi Pudji Rahayu* ${ }^{*}$, Edi Setiawan ${ }^{2}$, Meita Larasati ${ }^{3}$, Pahman Habibi ${ }^{4}$ \\ 1dewirahayu@uhamka.ac.id, ${ }^{2}$ edisetiawan@uhamka.ac.id, ${ }^{3}$ meita.larasati@uhamka.ac.id, \\ ${ }^{4}$ pahman_habibi@uhamka.ac.id \\ ${ }^{123}$ Universitas Muhammadiyah Prof. DR. HAMKA
}

\begin{abstract}
Purpose - This study aims to determine the effect of accountability and transparency of Islamic microfinance institutions on customer trust, with financial performance as an intervening variable in Islamic microfinance institutions, one of the significant microfinance in Indonesia. Methodology This research is a research gap, which tests the hypothesis (hypothesis testing) type causal. The aim is to determine the causal relationship between the independent variable and the dependent variable. The research location used in this study is the Central Java Sharia BTM (Islamic microfinance institution) in Indonesia, which has 36 members. The results of the test indicate that accountability partially influences performance significantly and is positive, while transparency did not significantly affect. Tested together shows the performance variables are influenced by accountability and transparency. While equation 2 contains four hypotheses. It can be concluded that the accountability and performance variables have an insignificant influence on people's trust, but the performance of ROA and BOPO has a significant effect on trust. When you look at the value of the test together, it can be concluded that accountability, transparency, and performance do not affect people's trust. Limitations of the Research - This research is only conducted in a small number of Islamic microfinance institutions in Indonesia. It is exclusively owned by Muhammadiyah NGOs with locations only in Central Java, so research needs to be done in different places. A separate study needs to be done between accountability and transparency on the dependent variable of public trust. Research needs to be done using non-financial performance. The scientific contribution of this research was conducted to connect several research variables from other separate studies and where the research was carried out in Indonesia, especially related to Islamic microfinance institutions.
\end{abstract}

Keyword : Accountability, Transparency, Financial

\section{Introduction}

Information in the digital era is now essential, it is because of the importance of equalizing perceptions between people, and even a more transparent attitude in the future becomes a demand [1]. Transparency can be considered as the right action because it can make strategic actions to connect organizational policies and economic factors. The economic agenda will influence the organization so that transparency becomes a movement that is needed [2]. On the other hand, accountability is an action to make good governance of the organization so that the organization can develop well. Included in this case are Non-Government Organizations (NGOs). The implication of this is that the better accountability of NGOs will have an impact 
on the achievement of goals and ideals through the implementation of policies that can be independently monitored [3],[4],[5],[6],[7]. However, [8] found that horizontal and vertical accountability will create tense relations between NGOs and donors, and if not managed properly will lead to social dysfunction, mainly related to NGOs who are involved in grassroots communities [9],[10],[11],[12].

Implementation of accountability and Transparency among community organizations, according to Rooney, G.not yet noticed. In his research [9],[13], generating accountability findings can increase the trust of donors. [14] examines transparency, accountability, and cooption of government towards NGOs, which analyzes four international NGOs in carrying out accountability and transparency. This research is supported by several other studies, as follows: [15] examines the relationship between accountability and transparency to muzzaki trust, and the results show that accountability and transparency affect muzzaki trust. Accountability, transparency and muzzaki trust positively affect the desire to pay zakat, the level of trust in muzakki mediates the effect of accountability on the willingness to pay zakat partially, the level of muzzaki trust mediates the effect of transparency on the desire to pay tax partially. And according to research conducted by [16], produces findings that the accountability and transparency of local government influence people's satisfaction and trust. [17]Transparency and accountability in the Surakarta Indonesia mosque give rise to a sense of public trust. It can provide a statement that the better the accountability and transparency, the better public trust will be. Research conducted by [18], states that trust has an essential role in organizations, in the study conducted by [18], states that there is a correlation between trust and performance of an organization carried out at the Ministry of Research and Higher Education in the country of Poland.

[19], stated about the implications that the more accountable and transparent NGOs are, it is essential because it makes NGOs better. Accountability and transparency research at NGOs was also carried out by [20], that NGOs have good transparency and accountability. Thus stated by [21]. But according to research, [22] stated NGO accountability is inadequate. And the cause of the difference is due to the absence of adequate standards in research on the performance and operations of non-government organizations [20]. However, a study conducted by [23] stated that there was no significant influence between transparency and muzakki's belief in amil zakat institutions. Likewise, research conducted by [24] held in the Sorong local government obtained results that there was no significant relationship between accountability and performance. The principle of transparency means that government administrators must be open to the people, that in making decisions and policies as well as in implementation and control, especially everyone related to a decision needs to have access to obtain the required information [25]. So transparency, in this case, has the meaning of communicating policies to the public openly, the community can freely access information. According to research conducted by [26], transparency has a construct of openness, and there is enough information and is easy to understand and easy to evaluate.

[27] examined that the accountability of women's NGOs in India showed a relationship of decreased accountability to the decline in NGO performance. [28] that, accountability will increase the existing public trust in Iranian society. In addition to the study, a lot of research related to accountability and transparency is related to financial performance, but on average it is related to local government finances. [29] examined the accountability and transparency of regional financial management that had a positive effect on the performance of the Regional Government of Jember Regency in Indonesia. In line with the research also has been carried out by [30], ), [31]. [32] examines the relationship between accountability and transparency on school productivity in the Magelang region of Indonesia and the results there is a positive 
influence between accountability and transparency on productivity. [33], produces research on the positive influence between accountability, transparency, and public participation on service performance in Pasaman Barat Regency, West Sumatra Indonesia. So it can be concluded that the better accountability, the better the performance of an institution.

Microfinance institutions are financial institutions that include micro-businesses, microinsurance, micro-credit micro-finance businesses, and other micro-finance institutions. The hope is that these microfinance institutions can be accessed by the poor [34]. Furthermore, Islamic microfinance institutions are considered as different from conventional microfinance institutions. Islamic microfinance institutions are regarded as better financial institutions because they prioritize morals and godliness (Tauhid)[35].

The purpose of this study is to re-examine the effect of accountability and transparency of Islamic microfinance institutions on financial performance. The second is to determine the effect of accountability, transparency, and performance of Islamic microfinance institutions on customer trust. This research is different from previous studies because it was conducted at Islamic microfinance institutions in Indonesia, which are an inseparable part of one of the major NGOs in Indonesia. This research will build empirical and factional gab from previous studies.

\section{Literature Review}

\section{Theoretical framework}

Theory of Planned Behavior(TPB) is an extension of the Theory of Reason Action (TRA)[36],[37]. TPB, as individual performance of certain behaviors, is measured by the seriousness of the performance of the behavior. Seriousness itself is informed by attitudes that prioritize behavior, subjective norms that lead to behavior and perceptions about how individuals will successfully engage in the intended behavior [38]. [36] suggests that TPB is an informed attitude as a result of behavior. So TPB will turn attitudes into desired behaviors or habits. For example, when people want to trust, what the organization does is how to make it believable, by increasing financial performance and promoting transparency as well as accountability.

The idea of [39] about Microfinance Institutions, first brought it to the Nobel Prize in 2006. The financial institution is called a poor bank (Grameen). This Microfinance Institution was initially intended for poor mothers in Bangladesh. The year 1993 was the earliest history for Grameen because the first idea of the bank of the poor was introduced in depth at the world bank forum, and received good response from donor countries in the world. Because the concept of a bank that helps poor people become more successful is a different concept from the concept of banks in general. Finally, the world community made it as a pilot project for microfinance institutions. Included in this case is Indonesian society. Indonesia is a country with a majority Muslim population, totaling around 85\% [41] and Muhammadiyah is one of the major Islamic NGOs in Indonesia. Muhammadiyah has business charities, which are very large in number. Finally, the Muhammadiyah NGO saw the opportunity and established a microfinance institution in Indonesia called Baitul Tamwil Muhammadiyah or BTM.

NGO was first introduced by [40] is a voluntary organization that is independent and flexible, and the very important thing is related to accountability, to make it achieve without disrupting independence and flexibility. [42] states that NGOs or NGOs are institutions that 
need better accountability so that there are no problems with the supervision and position of NGOs in the community.

AAOIFI (Accounting and Auditing Organization for Islamic Financial Institution) is an institution that issues regulations relating to new regulations related to accounting and auditing, and sharia committees that encourage the creation of a code of ethics in sharia business[43]. The agency also facilitates evaluations in the business financial instruments of Islamic financial institutions. In evaluating the performance of microfinance institutions, they can use income indicators (Financial Revenue), which include receipts of financial institutions that originate from the margin of financing and lending operations [44]. In measuring the ability of management to control operational costs against operating income, it is usually measured using a ratio so that the results are the more efficient the microfinance institution, the less likely it is to get problems.

In Indonesia, the measuring devices used to assess the health of microfinance institutions are determined by the regulation of the Ministry of Cooperatives and Small and Medium Enterprises of the Republic of Indonesia number 35.3/Per/M.KUKM/X/2007. It concerning the Guidelines concerning the financial health assessment of Islamic microfinance institutions requires health in terms of capital, quality of productive assets, management, efficiency, liquidity, independence and growth, participation, and compliance of sharia. The manifestations of the performance that will be used in this study include BOPO, FDR, KAP, CASH, CAR, PPAP, ROA, ATI ROE, and NPL. According to [45], BOPO, this ratio is used to measure the ability of management to control operational costs against operating income, so that the more efficient the operations of BTM, the less likely it is that BTM will get into trouble. FDR (Financial to Deposit Ratio) is the ratio between the amount of financing provided by BTM to third parties. To what extent is BTM's ability to repay withdrawals of funds made by savers by relying on loans given as liquidity. KAP (Earning Asset Quality), namely the coverage of earning assets components in accordance with the applicable Earning Asset Quality provisions. Figures are calculated per position (not annualized).CASH (Cash Ratio) is the ratio used to compare total cash and the company's cash equivalent with its current liabilities.CAR (Capital Adequacy Ratio) based on the capital adequacy ratio that shows the ability of BTM to provide funds used to overcome the possibility of loss risk. This ratio is important because by keeping CAR at a minimum limit of $8 \%$, it also means protecting customers and maintaining overall financial system stability. The higher the value of CAR reflects the ability of BTM, the better in dealing with the possibility of risk of loss. CAR can be obtained by dividing total capital by risk-weighted assets (RWA). PPAP, namely Allowance for Earning Asset Losses PPAP, is often used by BTM to see the burden of reserves when assets are needed to be written off. ROA (Return On Assets) is a ratio that measures the ability of banks to produce a profit by comparing net income with resources or total assets owned. The function is to see how effective banks are in using their assets in generating revenue. The higher the value of ROA means, the better the ability of banks to generate profits. ATI is a ratio to see the book value of assets to core capital. ROE(Return on Equity) is the calculation of core capital based on the provisions of the applicable Minimum Capital Requirements. NPL in Bank Indonesia Circular Letter Number 13/30 / DPNP dated December 16, 2011 [46], Non-Performing Loans (NPLs) is a financial ratio that shows credit risks faced by banks due to lending and investment of bank funds in different portfolios.

The concept of accountability in a study conducted by [47] includes a report and explanation. Accountability can be simply implied as financial reporting then how to explain the report, both the sanctions and rewards implications. These sanctions and rewards do not have a direct impact but information users will provide rewards and punishments to financial 
statement presenters related to accountability. The third is the relationship between the renderer (accountor) and user (accountee). The activity of the renderer (accountor) is an activity that can be accounted for because it uses careful calculation. And who are the accountees (users), namely all parties who need accountability, including those from individuals, offices, and organizations, especially government departments?

In his research, [9] noted several things to assess the accountability of non-profit organizations. Large non-profit organizations will pay dearly for accountability in increasing the trust of donors, want to know how well or pressure from regulators related to public services that have been done and related to tax issues. Accountability needs include for whom and how accountability can be created. Accountability for parties, including members of the organization, service organizations, policy advocacy networks (Policy Advocacy Network). And what for accountability, according to him accountability for finance, government, performance, and mission .

[48] there are four components of accountability: 1) Transparency is gathering information and making information easily accessible, available, and in-depth research 2) Answer and justification, prepare the reasons for activities and policies taken as the best answer, 3) Compliance, through monitoring and evaluation related to procedures and outcomes, by combining the transparency found, 4) Enforcement and sanctions related to lack of compliance, authentication or transparency. [48] define transparency as part of being accountable. Even in [20] research, they cannot define separately for transparency, accountability, and accountability. [49] sees more accountability in public spending by public institutions and more in accountability from the perspective of accounting reporting. According to[49], transparency and accountability are two words that are often considered the same. Transparency and public openness become essential when we want an accountable organization, and transparency must have published reports and even need to be given access to the public debate on this matter.

The principle of transparency means that government administrators must be open to the people, that in making decisions and policies as well as in implementation and control, especially everyone related to a decision needs to have access to obtain the required information [25]. So transparency, in this case, has the meaning of communicating policies to the public openly, the community can freely access information. [2] found a link between transparency and performance.

Accountability and transparency research at NGOs are also carried out by [28] that accountability will increase the existing public trust in Iranian society, and one factor of accountability is the factor of financial performance. [20] have research results that NGOs have good transparency and accountability. Thus stated by [21]. [19] stated about the implication that the more accountable and transparent the NGO is essential because it makes the NGO better, even though the assessment of accountability is complicated.

[27] examined that the accountability of women's NGOs in India showed a relationship of a decrease in accountability to a decline in NGO performance [3],[4],[5],[6],[7],[19]) found a link between accountability and transparency on performance. In addition to the study, a lot of research related to accountability and transparency is related to financial performance, but on average, it is related to local government finances.[29] examined the accountability and transparency of regional financial management that had a positive effect on the performance of the Regional Government of Jember Regency. In line with the research also has been carried out by [30], [31],[32], examines the relationship between accountability and transparency on school productivity in the Magelang region and the results there is a positive influence between accountability and transparency on productivity. [33], produces research on 
the positive impact between accountability, transparency, and public participation on service performance in Pasaman Barat Regency. So it can be concluded that the better accountability, the better the performance of an institution. Thus it can be hypothesized as follows:

H1: There is a positive influence between accountability on the partial performance of Islamic microfinance institutions

$\mathrm{H} 2$ : There is a positive influence between transparency on the performance of Islamic microfinance institutions partially.

H3: There is a positive influence between accountability and transparency on the performance of sharia microfinance institutions simultaneously

[9],[13], generating accountability findings can increase trust. Accountability can increase the trust of donors. [14] examines transparency, accountability, and co-option of government towards NGOs, which analyzes four international NGOs in carrying out accountability and transparency. Several other studies support this research, as follows: [15] examines the relationship between accountability and transparency to muzzaki trust, and the results show that accountability and transparency affect muzzaki trust. Accountability, transparency and muzzaki trust positively affect the desire to pay zakat, the level of trust in muzakki mediates the effect of accountability on the desire to pay zakat partially, the level of muzzaki trust mediates the impact of transparency on the desire to pay tax partially. And according to research conducted by [16] produces findings that the accountability and transparency of local government influence people's satisfaction and trust. [17] transparency and accountability in the Surakarta mosque give rise to a sense of public trust. It can be given that better accountability and transparency will make public trust also better. Research conducted by [ states that trust has a vital role in organizations, in a study conducted by [18], [51], states that there is a correlation between trust and performance of an organization carried out at the Ministry of Research and Higher Education in the country of Poland. So that the following hypotheses can be drawn:

H4: There is a positive influence between accountability on the partial trust of Islamic microfinance institutions

H5: There is a positive influence between transparency on the partial trust of Islamic microfinance institutions.

H6: There is a positive effect of performance on the partial trust of Islamic microfinance institutions

H7: There is a positive influence between accountability, Transparency and BTM performance together on BTM trust.

\section{Method}

This research is a study of a gab study that re-examines existing research, which will be answered by testing the hypothesis (hypothesis testing) type causal. The aim is to determine the causal relationship between the independent variable and the dependent variable. For this purpose, research is carried out by conducting field surveys, namely research by taking samples from a population and using a questionnaire as a primary data collection tool [52] In this research, in terms of time (time horizon), including cross-sectional studies, research where data collection is only done once (several days, several weeks, or several months, to answer research questions) [53]. 
The NGO examined in this study was Muhammadiyah. Muhammadiyah is a very large NGO in Indonesia. Research conducted by Alvara Center Research (2017) states that the most significant number of community organizations in Indonesia is Muhammadiyah. And the reason for the Muhammadiyah PWM was chosen because the Muhammadiyah Regional Leadership (PWM) of Central Java Province is a PWM in Indonesia which has many Baitul Tamwil Muhammadiyah (BTM) that are growing rapidly in the Central Java region and become a pilot in Indonesia. Mapping the potential of BTM has also begun to tidy; it is the main attraction of researchers to start research accountability and transparency at the BTM AUM in Central Java. Central BTM Central Java has an ever-increasing number of members, from year to year, and currently, there are as many as 36 BTM members, scattered in the area of Central Java Province. The study was conducted for three months, from September to November 2017.

\subsection{Research Variables}

The variables in this study are composed of: The dependent variable, consisting of 2 variables, namely in equation 1 namely performance and equation 2 , is community trust. While the independent variable, consisting of equation 1, namely accountability and transparency and equation 2 , namely accountability, transparency, and performance.

\subsection{Variable Operations}

Accountability Variable, no standard becomes a consensus on the definition of accountability because of the broad meaning of accountability. This study will use the definition of accountability by definition [54] with the construct of accountability variables as follows: Financial Statements, answers and justifications, sanctions, and rewards to accountants and compliance.Transparent Variable. The researcher uses the transparency construct according to the research [26] Performance Variable, the performance construct here is the financial performance of financial institutions as stipulated in the performance evaluation of the Sharia Financial Services Cooperative / Sharia Financing Cooperative / Sharia Savings and Credit Cooperative. Regulation of the Minister of Cooperatives and Small and Medium Enterprises of the Republic of Indonesia, No. 35.3 / Per / M.KUKM / X / 2007. Which consists of CAR, KAP, PPAP, ROA, BOPO, CASH, FDR, ROE, NPLs, and ATI.

The Trust variable here has a construct as community trust through increased lending and savings customers.

\subsection{Data Tabulation}

Data obtained from surveys are collected, edited to determine the completeness of questionnaires, and quantified or given a score so they can be processed statistically. The steps taken are:

1 Each answer from the questionnaire was scored using the "Likert Scale."

For questions that are positive, scoring follows the following rules:

BC / SS : Very easy / Very Agree, score 5

$\mathrm{M} / \mathrm{S} \quad$ : Easy / Agree, score 4

S / R : Moderate / Doubtful, score 3

ST / TS : Difficult / Disagree, score 2

SST / STS : Very Difficult / Very Disagree, score 1

As for negative questions, scores are given with the following provisions:

BC / SS : : Very easy / Very Agree, score 1 
$\mathrm{M} / \mathrm{S} \quad$ : Easy / Agree, score 2

S / R : Moderate / Doubtful, score 3

ST / TS : Difficult / Disagree, score 4

SST / STS : Very Difficult / Very Disagree, score 5

2. Tabulate respondents' answers for each of these questions.

3. Test using SPSS to answer the proposed hypothesis.

\section{Result And Discussion}

Of all the questionnaires that have been collected and sorted out their eligibility, obtained ten respondent data from 2012 to 2016. Still, from these data, there are 2 BTM that do not provide complete performance data, namely BTM Tegal City because it had not yet operated in 2012 and However, the data will still be used in 2014 to 2016. The BTM Kedungwuni in 2016 has not yet calculated its financial performance, so for the previous year, it was even included as data. So the total amount of data collected is a number

Table 1. Recapitulation of Questionnaire Collection Results

\begin{tabular}{lcccc}
\hline BTM member & $\begin{array}{c}\text { Distributed } \\
\text { questionnaire }\end{array}$ & $\begin{array}{c}\text { Questionnaire } \\
\text { that can be used }\end{array}$ & $\begin{array}{c}\text { Incomplete } \\
\text { questionnaire }\end{array}$ & $\begin{array}{c}\text { A questionnaire } \\
\text { that was not } \\
\text { responded to }\end{array}$ \\
\hline 36 BTM & 36 & 10 & 0 & 26 \\
\hline \multicolumn{5}{c}{ Source: data processed by the author }
\end{tabular}

Table 2. Recapitulation of Questionnaire Collection Results

\begin{tabular}{ccc}
\hline Information & total & Total Data \\
\hline $\begin{array}{c}\text { BTM that collected in 2012-2016 (5 } \\
\text { years) }\end{array}$ & 8 & 40 \\
\hline $\begin{array}{c}\text { BMT Tegal operates from 2014-2016 } \\
\text { (3 years) }\end{array}$ & 1 & 3 \\
\hline $\begin{array}{c}\text { BTM Kedungwuni in 2012-2015 (4 } \\
\text { years) }\end{array}$ & 1 & 4 \\
\hline $\begin{array}{c}\text { Total number of samples collected } \\
\text { Source: Processed data }\end{array}$ & 47 \\
\hline
\end{tabular}

\section{Source: Processed data}

\section{Analysis of Research Results}

Test of the Effect of Independent Variables on Dependent Variables

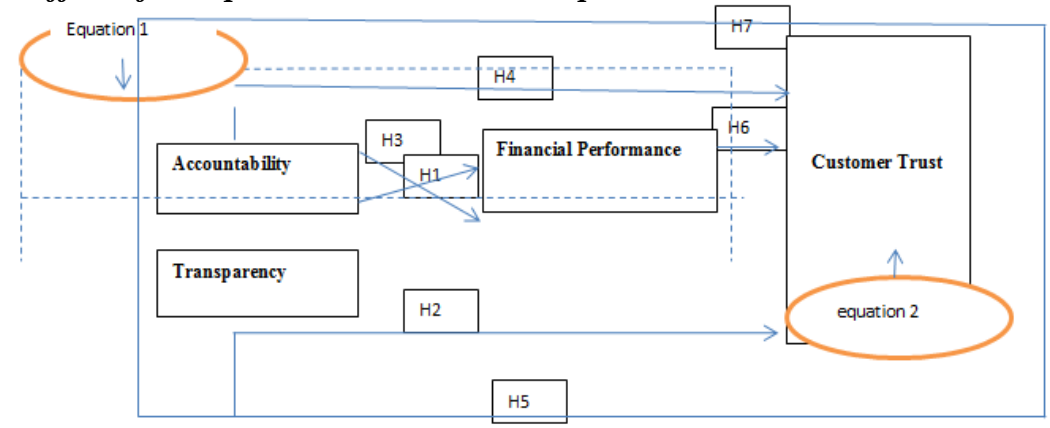

Fig.1. Research Model 
Yko $=\mathrm{a}+\mathrm{b} 1 \cdot \mathrm{Xa}+\mathrm{b} 2 \cdot \mathrm{Xt}+\mathrm{e}$

The regression equation in this study can be stated by:

$\mathrm{Y}=29937,153-0,308 . \mathrm{X} 1+0,218 . \mathrm{X} 2+\mathrm{e}$

The equation can be interpreted as follows.

a. The constant of 29937,153 means that in the condition of the predictor variable = 0 , the level of consistent performance is 29937,153 .

b. The multiple linear regression coefficients for the accountability variable of 0.308 indicates that any additional accountability will reduce performance by 0.308 , assuming the other independent variables are fixed (ceteris paribus).

c. The multiple linear regression coefficients for the transparency variable of 0.218 indicates that any transparency made will improve performance by 0.218 , assuming the other independent variables are fixed (ceteris paribus).

By using $\alpha=5 \%$, the results of the regression analysis of the SPSS program after the classical assumption test can be presented in the following table [55].

Table 3. Summary of Regression Analysis Results

\begin{tabular}{lcrrc}
\hline \multicolumn{1}{c}{ Variable } & $\begin{array}{c}\text { Regression } \\
\text { Coefficient (Beta) }\end{array}$ & T & Significance & Information \\
A constant & $29,937,153$ & 2,195 & 0.034 & Significant \\
Accountability & $-0,308$ & $-2,186$ & 0.034 & Significant \\
Transparency & 0.218 & 1,545 & 0.130 & Not significant \\
\hline & $\boldsymbol{\alpha}=5 \% \mathrm{~F}=3,837(.0,029)$ & $\mathrm{R}=38.9 \% \mathbf{R 2}=15.1 \%$ &
\end{tabular}

H1: There is a positive influence between accountability on the performance of BTM partially

It can be seen that of the three independent variables included in the regression test; all are significant. It can be seen from the significance that there are successively from the accountability and transparency variables valued at 0.034 and 0.130 ; the accountability variable has a value lower than 0.05 (PV). With a confidence level of 95\%, obtained t table \pm 2,117 and $t$ arithmetic of $-2,186$. Therefore $t$ arithmetic $>\mathrm{T}$ table, then H1, is accepted. So it can be concluded that Financial Performance is influenced by the independent variable of accountability,

$\mathrm{H} 2$ : There is a positive influence between transparency on the performance of BTM partially.

The transparency variable does not have significant value because it has a significantly greater value than 0.05 , namely 0.130 . Or with a $95 \%$ confidence level, obtained $t$ table \pm 2.117 and $t$ arithmetic for 1.545 . Because $t$ arithmetic $<t$ table, Hal cannot be accepted. So it can be concluded that transparency does not have a significant effect on performance.

The global test aims to test the ability of all variables $\mathrm{X}(\mathrm{X} 1, \mathrm{X} 2$, and $\mathrm{X} 3)$ together to explain the behavior of the dependent variable Y. In other words, the F Test is used to determine whether the independent variables (Transparency and accountability) jointly influence the performance. The hypothesis formulation is:

H3: There is a positive influence between accountability and Transparency on BTM performance simultaneously

From the results of the table above, it can be seen that $\alpha=5 \%, \mathrm{~F}=3.837$, with a significance value of 0.029 . Because the significance of $F$ is less than 0.05 , it can be concluded that $\alpha=5 \% \mathrm{H} 3$ is accepted. The assumption is that together the three independent variables above affect BTM performance. 
Based on Table 3 above, the correlation coefficient $(\mathrm{R})$ value is $38.9 \%$. It shows that there is a strong relationship between transparency and accountability towards the independent variable (the limit used is 0.5 or $50 \%$ ), or the independent variable influences the dependent variable in the direction of a positive correlation. Because the variables are more than two, an Adjusted R Square is used with a value of $15.1 \%$. And it can be concluded that the independent variable is only able to explain the effect on the compliance variable by $15.1 \%$. Thus, it can be concluded that this research model is more influenced by factors outside the study that is equal to $85.9 \%$.

\section{Equation 2}

$\mathrm{Ykm}=\mathrm{a}+\mathrm{b} 1 \cdot \mathrm{Xa}+\mathrm{b} 2 \cdot \mathrm{Xt}+\mathrm{b} 3 \cdot \mathrm{Xk}+\mathrm{e}$

The regression equation in this study can be stated by:

$\mathrm{Y}=102117,577+0,143 \cdot \mathrm{X} 1+0,215 \cdot \mathrm{X} 2+0,201 . \mathrm{Xk} 1+\ldots . .+\mathrm{e}$

The equation can be interpreted as follows.

a. The constant of 102117,557 means that in the condition of the predictor variable $=0$, the level of consistent performance is 102117.557.

b. The multiple linear regression coefficients for the accountability variable of 0.143 indicates that any additional accountability will reduce performance by 0.143 , assuming the other independent variables are fixed (ceteris paribus).

c. The multiple linear regression coefficients for the transparency variable of 0.215 indicates that any transparency performed will improve performance by 0.215 , assuming the other independent variables are fixed (ceteris paribus).

d. The multiple linear regression coefficients for the performance variable of 0.201 indicates that any transparency made will improve performance by 0.201 , assuming the other independent variables are fixed (ceteris paribus).

Using $\alpha=5 \%$, the results of the regression analysis of the SPSS program after the classical assumption test [55], can be presented in the following table:

Table 4. Summary of Regression Analysis Results

\begin{tabular}{|c|c|c|c|c|}
\hline Variable & $\begin{array}{c}\text { Regression } \\
\text { Coefficient } \\
\text { (Beta) }\end{array}$ & $\mathbf{t}$ & Significance & Information \\
\hline A constant & $10,217,577$ & 2,716 & .10 & Significant \\
\hline Accountability & .143 & 1,197 & 0.603 & Not significant \\
\hline Transparency & 0.215 & .878 & 0.730 & Not significant \\
\hline CAR Performance & $-0,201$ & $-1,073$ & .291 & Not significant \\
\hline KAP performance & $-0,351$ & $-0,956$ & .346 & Not significant \\
\hline PPAP performance & $-0,076$ & $-0,433$ & 0.668 & Not significant \\
\hline ROA performance & $-0,350$ & $-2,133$ & 0.04 & Significant \\
\hline BOPO Performance & $-0,456$ & $-2,768$ & 0.09 & Significant \\
\hline CASH performance & $-0,030$ & $-0,191$ & 0.850 & Not significant \\
\hline FDR performance & $-0,260$ & $-1,705$ & 0.98 & Not significant \\
\hline ROE performance & $-0,085$ & $-0,296$ & 0.769 & Not significant \\
\hline NPLs Performance & $-0,131$ & $-0,363$ & 0.719 & Not significant \\
\hline ATI performance & .246 & 1,092 & 0.285 & Not significant \\
\hline
\end{tabular}

H4: There is a positive influence between accountability in partial trust in BTM

With a confidence level of $95 \%$, the results obtained by ROA performance have the results of $t$ table \pm 2.117 and $t$ arithmetic of 1.197. Because $t$ arithmetic $<t$ table, then $\mathrm{H} 1$ is rejected. Meanwhile, the results of calculations using SPSS show that the accountability variable has a 
significance value of 0.386 , so it can be concluded that accountability does not positively influence people's trust at the $95 \%$ confidence level. So, the more adequate the accountability, then it does not make the increase of trust.

H5: There is a positive influence between Transparency on BTM's partial trust.

With a $95 \%$ confidence level, obtained t table $\pm 2,117$ and $t$ arithmetic of 0.878 . Because $t$ arithmetic < t table, then $\mathrm{H} 2$ is rejected. Meanwhile, the results of calculations using SPSS show that the transparency variable has a significance value of 0.240 and is positive on the $t$ value. So it can be concluded that transparency does not have a significant effect on people's trust.

H6: There is a positive effect of performance on BTM's partial trust

$\mathrm{T}$ arithmetic and t table for ROA and BOPO with $95 \%$ confidence level, obtained table \pm 2,117 and $t$ arithmetic of $-2,133$ and $-2,768$ then $t$ arithmetic $>t$ table, so H3 for ROA and BOPO is accepted. Meanwhile, the results of calculations using SPSS indicate that the ROA and BOPO performance variables have significant values of 0.040 and 0.09 . So it can be concluded that the performance of ROA and BOPO significantly affects the $95 \%$ confidence level and has a negative influence. So the better the performance of ROA and BOPO, the Level of Community Trust in BTM will not increase.I

Performance variables such as CAR, KAP, PPAP, CASH, FDR, ROE, NPLs, and ATI do not have a significant effect on trust. It can be seen that of the three independent variables included in the regression test, all are insignificant except for two performance variables, namely ROA and BOPO variables. So it can be concluded that the performance of BTM (ROA and BOPO) influences public trust.

H7: There is a positive influence between accountability, transparency, and BTM performance together on BTM trust.

According to the table above, the significance value is smaller than 0.05 , with a value of 0.01 , then $\mathrm{H} 7$ can be accepted. So that together, the three variables above have a significant influence on community trust. Based on Table 4 above, the correlation coefficient $(\mathrm{R})$ value is $35.8 \%$. Because the variables are more than two, an Adjusted R Square is used with a value of $12.4 \%$. And it can be concluded that the independent variable is only able to explain the effect on the compliance variable by $12.4 \%$. Thus, it can be concluded that this research model is more influenced by factors outside the study that is equal to $87.6 \%$

The above findings related to the relationship between transparency and accountability of microfinance institutions to financial performance have a significant positive relationship. This is following research conducted by [19],[29],[30].[31],[33]. Next accountability has an influence on performance following research conducted by [27], [3],[4],[5],[6],[7],[19]. However, the results of research related to transparency found anomalous results with the results of previous studies [2].

While research that links transparency, accountability, and performance of microfinance institutions to customer trust is in accordance with the research conducted [9],[14],[13],[28],[15],[16],[17] that is, together accountability and transparency have an influence on people's trust. However, partially accountability and transparency have anomalous results that are not related to public trust, except related to performance (BOPO and ROA). This is in accordance with research conducted by [50], [51]). 


\section{Conclusion}

In this study, it can be concluded that in equation 1, there are 3 hypotheses, partially accountability influences performance significantly, whereas transparent variables do not significantly influence. The model together shows a significant value. The performance variables are influenced by accountability and transparency. It's regression coefficient $\mathrm{R}$ of $38.9 \%$ and a coefficient of $\mathrm{R} 2$ of $15.1 \%$. It means that there are outside variables that have not been researched at $84.9 \%$, which influences performance. Accountability has a negative effect, meaning that the more accountable, the worse the performance.

Equation 2, there are 4 hypotheses, which can be concluded that the accountability and performance variables have an insignificant influence on public trust. Still, ROA and BOPO performance have a significant effect on trust, while the other performance variables have no significant impact. And if you look at the value of the test together, it can be concluded that accountability, transparency, and performance affect people's trust. With a regression coefficient R of $59.8 \%$, while a coefficient of R2 of $35.8 \%$, which means that there are outside variables that have not been researched at $64.2 \%$, which influences performance. These results agree with the research conducted by[9],[14],16],[17].

Recommendations from this study are Muhammadiyah NGOs in Indonesia so that they pay attention to accountability and transparency as well as their financial performance even though public trust is high enough.

There are several limitations of this research that need further research, namely:

a. Because the number of BTM responding to the questionnaire is still very small, so the above model needs to be re-examined with different respondents. And different forms of questionnaire questions.

b. Separate research needs to be done between accountability and transparency on the dependent variable of public trust, or the performance variable by issuing variables KAP, ROE, NPLs, and ATI. Or 10 performance variables to be reprocessed.

c. This research also proves that the public is still ignorant of the importance of accountability and transparency, and the lack of accountability of financial presentations is carried out so that the hypothetical model with results has no effect.

\section{Reference}

[1] Austin, R., \& Upton, DM (2016). Leading in the age of super-transparency. MIT Sloan Management Review, 57 (2), 25.

[2] Nolin, JM (2018). Defining transparency movements. Journal of Documentation.

[3] Commission for Africa Report (2005), "Commission for Africa Report", available at: http: // 213. 225.140.43 / english / report / introduction.html \# report

[4] Kaldor, M. (2003), Civil Society and Accountability, Journal of Human Development, Vol. 4 No. 1, pp. 5-27.

[5] Kovach, H., Neligan, C. and Burall, S. (2003), The Global Accountability Report 1, 2003: Power without Accountability?, One World Trust, London.

[6] Lewis, D. and Madon, S. (2004), Information systems and nongovernmental development organizations: advocacy, organizational learning, and accountability, The Information Society, Vol. 20, pp. 117-26. 
[7] Zadek, S. (2003), "In defense of non-profit accountability", Ethical Corporation Magazine, September, pp. 34-6.

[8] Dixon, R., Ritchie, J., \& Siwale, J. (2006). Microfinance: accountability from the grassroots. Accounting, Auditing \& Accountability Journal, 19 (3), 405-427.

[9] Ebrahim, A. (2003), Accountability in practice: mechanisms for NGOs, World Development, Vol. 31 No. 5, pp. 813-29.

[10] Ebrahim, A. (2005), Accountability Myopia: Losing Sight Of Organizational Learning, Nonprofit and Voluntary Sector Quarterly, Vol. 34 No. 1, pp. 56-87.

[11] Hillhorst, D. (2003), The Real World of NGOs: Discourses, Diversity and Development, ZED, London.

[12] Naidoo, K. (2003), "Who guards the guardians? The accountability and governance of NGOs Workshop, April 3 2003, UN Headquarters, New York ", available at: www.civicus.org/new/ media / NGOAccountability.doc (accessed December 6 2004).

[13] Keating, VC, \& Thrandardottir, E. (2017). NGOs, trusts, and the accountability agenda. The British Journal of Politics and International Relations, 19 (1), 134-151.

[14] Lawrence, PG, \& Nezhad, S. (2009). Accountability, transparency, and government co-option: A case study of four NGOs. International NGO Journal, 4 (3), 076-083.

[15] Safrizal. (2015). The Effect of Accountability and Transparency of Zakat Institutions on the Level of Trust in Muzakki and Its Impact on the Desire to Pay Zakat in Baitul Mal, East Aceh District. Unpublish Thesis. Aceh: Syiah Kuala University.

[16] Rahmawati, NE, \& Basuki, H. (2013). The Effect of Regional Government Accountability and Transparency on Community Satisfaction and Trust (Doctoral dissertation, Gadjah Mada University).

[17] Hanafi, R., \& Zulfikar, SEM (2015). Accountability and Financial Management of the Mosque through the Phenomenology Approach (Empirical Study of the Nurusy Syifa Mosque in Jakarta) (Doctoral dissertation, Muhammadiyah University, Surakarta).

[18] Paliszkiewicz, J. (2012). Managers' orientation on trust and organizational performance. Jindal Journal of Business Research, 1 (2), 153-161.

[19] Gray, R., Bebbington, J., \& Collison, D. (2006). NGOs, civil society and accountability: making the people accountable to capital. Accounting, Auditing \& Accountability Journal, 19 (3), 319348.

[20] Pamungkas, AR, \& Hariadi, B. (2015). Analysis of Implementation of the Principles of Accountability and Transparency in Non-Government Organizations. FEB Student Scientific Journal, 4 (1)

[21] Husaini, H., \& Lisnawati, L. Analysis of the Effect of Accountability and Transparency in Regional Financial Management on Local Government Performance. Fairness, 3 (1), 23-40.

[22] Paskual, M. F., \& Ansar, M, (2011). Akuntabilitas LSM, Milik Donor atau Publik?(Studi Analisis Wacana Studi Pada Kantor Eksekutif Daerah Walhi Sulawesi Tengah)

[23] Hasrina, CD, Yusri, Y., \& Sy, DRA (2018). The Effect of Accountability and Transparency of Zakat Institutions on the Level of Muzakki's Trust in Paying Zakat in Baitul Mal, Banda Aceh City. Journal of Humanities, 2 (1), 1-9.

[24] Jitmau, F., Kalangi, L., \& Lambey, L. (2017). The Effect of Accountability, Transparency and Internal Audit Function on Local Government Performance (Empirical Study in Sorong Regency). Journal of Accounting and Auditing Research "Goodwill", 8 (1).

[25] Pieris, J. and Nizam JW (2008). "Business Ethics \& Good Corporate Governance, Second Edition". Jakarta: Pelangi Scholar

[26] Rahayu, DP, \& Harnanto, M. (2006). The effect of tax knowledge, tax expenditure transparency, and tax justice on tax compliance on taxpayers in Surakarta City (Doctoral dissertation, Gadjah Mada University).

[27] Kilby, P. (2006). Accountability for empowerment: Dilemmas facing non-governmental organizations. World Development, 34 (6), 951-963.

[28] Fard, HD, \& Rostamy, AAA (2007). Promoting public trust in public organizations: Explaining the role of public accountability. Public Organization Review, 7 (4), 331-344. 
[29] Riswanto, N. (2016). Analysis of the Effect of Accountability and Transparency in Regional Financial Management on the Performance of the Regional Government of Jember Regency. Department of Accounting, Faculty of Economics, University of Jember (UNEJ)

[30] Muljo, HH, Kurniawati, H., \& Pahala, P. (2014). The Effect of Accountability and Transparency on Budget Management. Binus Business Review, 5 (2), 537-550.

[31] Adliana, DW (2016). The Effect of Accountability, Transparency, and Supervision on the Performance of the Budget Concept of Value for Money in the Regional Work Unit of South Labuhanbatu Regency. The Effect of Accountability, Transparency, and Supervision on the Performance of the Budget Concept of Value for Money in the Regional Work Unit of South Labuhanbatu Regency.

[32] Setyawan, MHD (2015). The Influence of the Principle of Justice, Transparency and Accountability of Budget Management on School Productivity (Perception Gurusmp N 3 Mertoyudan Magelang) (Doctoral Dissertation, Semarang State University).

[33] Putra, H. (2014). The Effect of Accountability, Transparency and Public Participation on the Performance of Public Service Organizations. Unpublish Thesis. Padang: Padang State University.

[34] Ahmed, S. (2009). Microfinance institutions in Bangladesh: achievements and challenges. Managerial Finance, 35 (12), 999-1010.

[35] Tijani, IM (2015). A Proposed Regulatory Framework for Islamic Microfinance: Adopting the IFSA 2013 Approach. ISRA International Journal of Islamic Finance, 7 (1), 169.

[36] Ajzen, I. (1985). From intentions to actions: A theory of planned behavior. In Action control (pp. 11-39). Springer, Berlin, Heidelberg.

[37] Ajzen, I. (1991). The theory of planned behavior. Organizational behavior and human decision processes, 50 (2), 179-211.

[38] George, JF (2004). The theory of planned behavior and Internet purchasing. Internet research, 14 (3), 198-212.

[39] Yunus, M. (2003). Banker to the poor: The story of the Grameen Bank. Aurum Press Limited.

[40] Leat, D. (1988). Voluntary organizations and accountability. Policy Analysis Unit, National Council for Voluntary Organizations.

[41] Central Bureau of Statistics, (2010), Population by Age Group and Religion, https://sp2010.bps.go.id/index.php/site/tabel?tid=320\&wid=0

[42] Tilt, CA (2007). NGOs: Issues of accountability.

[43] Pomeranz, F. (1997). The accounting and auditing organization for Islamic financial institutions: An important regulatory debut. Journal of International Accounting, Auditing and Taxation, 6 (1), 123-130.

[44] Widiarto, I., \& Emrouznejad, A. (2015). Social and financial efficiency of Islamic microfinance institutions: A Data Envelopment Analysis application. Socio-Economic Planning Sciences, 50, $1-17$.

[45] Harun, U. (2016). The Influence of Car, Ldr, Nim, Bopo, Npl Financial Ratios Against Roa. Journal of Business and Management Research, 4 (1), 67-82.

[46] No, SEBI (2014). 13/30 / DPNP dated December 16, 2011. Accessed from www. bi. go id.

[47] Patton, JM (1992). Accountability and governmental financial reporting. Financial Accountability \& Management, 8 (3), 165-180.

[48] Ebrahim, A. (2005), Accountability Myopia: Losing Sight Of Organizational Learning, Nonprofit and Voluntary Sector Quarterly, Vol. 34 No. 1, pp. 56-87.

[49] Bovens, M. (2005). Public accountability: A framework for the analysis and assessment of accountability arrangements in the public domain. Unpublished paper.

[50] Paliszkiewicz, JO (2011). Trust Management: Literature Review. Management (18544223), 6 (4).

[51] Guinot, J., Chiva, R., \& Mallén, F. (2013). Organizational trust and performance: Is organizational learning capability a missing link? Journal of Management and Organization, 19(5), 559.

[52] Singarimbun, M. and Effendi, S. (2006). Survey Research Methods. 
[53] Sekaran, U., \& Bougie, R. (2011). Business Research Methods: A skill-building approach.

[54] Ebrahim, A., \& Weisband, E. (2007). Global accountabilities. Cambridge: Cambridge

[55] Ghozali, I. (2006). SPSS Multivariate Statistics. Diponegoro University Publisher Agency. Semarang. 